\title{
Climatic Constraints to the Potential of Microsphaeropsis amaranthi as a Bioherbicide for Common Waterhemp
}

\author{
David A. Smith, David A. Doll, Daljit Singh, and Steven G. Hallett
}

Department of Botany \& Plant Pathology, Purdue University, 915 West State Street, West Lafayette, IN 47907. Current address of D. A. Doll: Department of Plant Pathology, University of California, Davis 95616. Accepted for publication 17 November 2005.

\begin{abstract}
Smith, D. A., Doll, D. A., Singh, D., and Hallett, S. G. 2006. Climatic constraints to the potential of Microsphaeropsis amaranthi as a bioherbicide for common waterhemp. Phytopathology 96:308-312.

The fungal plant pathogen Microsphaeropsis amaranthi is a candidate bioherbicide for the control of weedy Amaranthus species since it grows and sporulates readily in culture, is a pathogen of a number of important weed species, and is host-restricted to the family Amaranthaceae. This study was designed to determine the optimum and limiting environmental conditions for the efficacy of foliar applications of $M$. amaranthi for the control of common waterhemp. The greatest disease severity and the greatest plant biomass reductions were found when a prolonged leaf wetness period of $\geq 12 \mathrm{~h}$ at 18 to $24^{\circ} \mathrm{C}$ was provided after application. Disease severity and plant biomass reductions were greater when plants were

common waterhemp seedlings were sprayed in the field weekly through the summer of 2004 with conidial suspensions of M. amaranthi, only 7 of 14 applications resulted in disease and only 3 applications resulted in more than slight disease flecks. Moderate levels of disease were observed when applications had been made on days with moderate temperatures and leaf wetness duration in excess of $12 \mathrm{~h}$ following application. We confirm the pathogenicity of $M$. amaranthi against common waterhemp and demonstrate that the unformulated pathogen can cause disease in the field. Nonetheless, the weather conditions of the Midwestern United States, where common waterhemp control would be desired, are infrequently conducive to infection. The continued candidacy of $M$. amaranthi as a bioherbicide for the control of common waterhemp in the Midwestern United States will require that its efficacy under suboptimal environmental conditions be improved.
\end{abstract} treated at an earlier stage of development. Disease severity and impact were limited when shorter leaf wetness periods were provided, with negligible disease observed on plants provided with $\leq 6 \mathrm{~h}$ leaf wetness. When
Additional keywords: epidemiology, formulation, virulence enhancement.
The bioherbicide approach is founded upon the principle that a naturally occurring pathogen of a weed species can be used in a manner analogous to a chemical herbicide to control that weed $(5,11,24)$. Under natural conditions, the impact of plant pathogens, particularly pathogens of wild or weedy hosts is strongly limited by factors of the host (e.g., dispersed populations), the pathogen (e.g., limited dispersal), and the environment (e.g., sporadic occurrences of weather conditions conducive to infection). In the bioherbicide approach, the goal is to increase the impact of the pathogen by one or more methods, such as application at inundative levels and timely application to a known susceptible population (11).

The fungal plant pathogen Microsphaeropsis amaranthi (Ell. \& Barth.) has a number of characteristics that makes it a worthy candidate for development as a bioherbicide. It is easily cultured, grows rapidly and sporulates freely on a number of artificial media (22), is host-restricted to the family Amaranthaceae (15), and is a pathogen of a number of important weeds in the genus Amaranthus $(7,15,16,23)$. Smith and Hallett (23) showed a positive interaction between $M$. amaranthi and the herbicide glyphosate. Concentrations of glyphosate and $M$. amaranthi that did not cause mortality alone killed common waterhemp when applied sequentially. Ortiz-Ribbing and Williams (16) observed $97 \%$ mortality of common waterhemp and 74 to $100 \%$ mortality of seven other Amaranthus spp. sprayed with conidia of $M$. amaranthi in the field. In this case, no supplemental irrigation was supplied, but the

Corresponding author: S. G. Hallett; E-mail address: halletts@purdue.edu

DOI: 10.1094/PHYTO-96-0308

(c) 2006 The American Phytopathological Society weather conditions were unusually warm and wet in the days following application.

Common waterhemp (Amaranthus rudis Sauer) has become a particularly troublesome weed in the Midwestern United States in the last 2 decades due to its adaptedness to no-till corn and soybean production, which has become increasingly prevalent during that time period $(6,12)$, and as a result of the evolution of a wide range of herbicide-resistant biotypes in the region, some of which are widespread $(17,18)$. Common waterhemp frequently escapes current weed management programs and can become a singlespecies problem, particularly in soybeans, and therefore represents a viable target for the bioherbicide approach utilizing a hostrestricted organism. The feasibility of integrating $M$. amaranthi into herbicide-dominated weed management systems to deliver enhanced control of common waterhemp has been discussed by Smith and Hallett (23), who have shown a synergistic interaction between $M$. amaranthi and the herbicide glyphosate.

The objective of this study was to determine the optimum and limiting conditions for infection and impact of common waterhemp by M. amaranthi. Determination of the optimum conditions is important to enable effective study of the organism in the controlled environment, and determination of the limiting conditions is important in understanding the requirements for improvement of the organism for effective bioherbicide activity in the field.

\section{MATERIALS AND METHODS}

Plant and fungal growth and maintenance, and fungal application. Seed of common waterhemp was pregerminated by soaking with agitation $\left(18 \mathrm{~h}, 20^{\circ} \mathrm{C}\right.$ ) in $0.05 \%$ (wt/vol) gibberellic acid $\left[\mathrm{GA}_{3}\right]$ and then sown onto a commercial potting mix (Metro 
Mix 360, Hummert International, Earth City, MO) and maintained in the greenhouse. The isolate of $M$. amaranthi was recovered from soil cultures and maintained on V8 agar (21). Conidia were harvested from young colonies (10 to 14 days) for each experiment by scraping with a sterile cotton swab, filtering through four layers of cheesecloth, and adjusting conidial concentrations with the aid of a hemacytometer. Applications were made using XR8003 nozzle tips (Teejet Midtech Midwest, Urbandale, IA) and a spray volume of 548 liters/ha in a commercial spray chamber. Unless otherwise stated, plants were moved to a dew chamber (Percival Science, Perry, IA) immediately after treatment where they were maintained with constant leaf wetness until being returned to the greenhouse.

Effect of temperature on germination and growth. Conidia of $M$. amaranthi were incubated in 1/4-strength potato dextrose broth in 10 -mm-diameter cell culture plates on a temperature gradient table at $5,10,15,20,25,30$ or $35^{\circ} \mathrm{C}$. Conidial germination was measured using four views of 25 conidia in six wells after $24 \mathrm{~h}$. Similarly, M. amaranthi mycelial plugs were placed onto V8 agar in the center of 90 -mm-diameter petri dishes on the temperature gradient table and colony diameters were measured after $48 \mathrm{~h}$. Percent conidial germination and colony diameter were measured and regressed against incubation temperature using Sigma Plot (SPSS, Chicago, IL).

Duration and temperature of leaf wetness period. Waterhemp seedlings were grown to the three- to four-leaf stage and sprayed with $3 \times 10^{6}$ conidia per $\mathrm{ml}$ as described previously. Directly after application, plants were supplied leaf wetness periods of $0,6,12$, and $18 \mathrm{~h}$ at temperatures of $14,18,23$, and $28^{\circ} \mathrm{C}$ in a dew chamber and then returned to the greenhouse. Disease ratings were taken 10 days after application on the following scale: $0=$ no disease, $1=$ slight flecking, $2=$ mild disease symptoms $(<10 \%$ necrosis), $3=$ moderate/severe disease symptoms (10 to $50 \%$ necrosis), $4=$ severe disease symptoms ( $>50 \%$ necrosis), and $5=$ plant death. Aboveground plant parts were harvested 10 days after application by cutting at the soil level, and biomass was measured after drying at $65^{\circ} \mathrm{C}$ for $72 \mathrm{~h}$. The experiment was arranged in a randomized complete block design with six replicates of six plants (subsamples) per replicate performed three times, and data were combined following tests for homogeneity of variances. Dry weight data were analyzed using PROC REG in SAS (SAS Institute, Cary, NC) and plotted in Sigma Plot (SPSS, Chicago, IL) with dry weights expressed as a percentage of water-sprayed controls. Disease mortality data were analyzed using Duncan's mean separation with PROC GLM in SAS.

Effect of plant age and conidial concentration. Common waterhemp seedlings were grown to the cotyledon, two- to three-

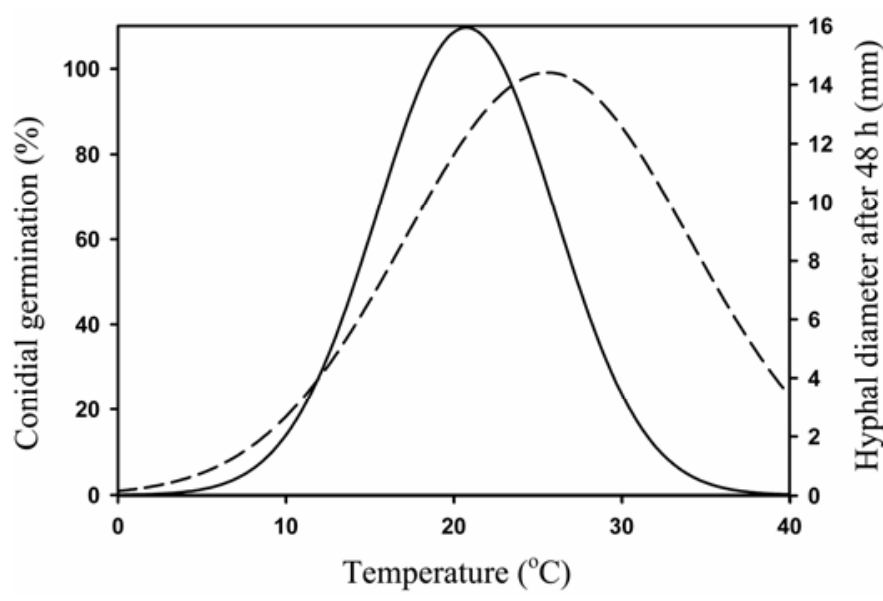

Fig. 1. The effect of temperature on Microsphaeropsis amaranthi conidial germination and hyphal growth in vitro. - Conidial germination $R^{2}=0.91$; - - - Hyphal growth $R^{2}=0.95$. leaf, four- to six-leaf, or eight- to nine-leaf stages of development and then sprayed, as described above, with conidial concentrations of $0,1 \times 10^{5}, 1 \times 10^{6}, 3 \times 10^{6}$, or $1 \times 10^{7}$ conidia per ml. Plants were placed in an $18^{\circ} \mathrm{C}$ dew chamber for $18 \mathrm{~h}$ immediately after application and then returned to the greenhouse. Disease ratings, biomass measurement, experimental design, and data analysis were performed as described above, except that this experiment was performed only twice.

Disease expression in the field. Common waterhemp seedlings were raised to the one- to two-leaf stage in the greenhouse and then moved outside and watered as needed. When plants reached the five- to six-leaf stage, they were brought indoors, sprayed with a suspension of $M$. amaranthi conidia $\left(10^{6}\right.$ conidia per $\mathrm{ml}$ as described above), and then immediately moved back outside. Sprays were performed in the same way at 6:00 p.m. every Thursday from 15 April 2004 to 15 July 2004. Plants were not covered in the field and were not watered for at least $15 \mathrm{~h}$ after application. Disease expression of $M$. amaranthi on each plant was recorded 14 days after application on a 5-point scale, where $0=$ no disease, 1 = slight flecks on foliage or stems, 2 = spreading lesions on the leaf or stem $(<20 \%$ necrosis), $3=$ moderate to severe foliar symptoms ( $>20 \%$ necrosis) or stem girdling, and $4=$ plant death. The experiment was a randomized complete block design with replicate plants per treatment. The weather data recorded were leaf wetness duration, rainfall, and temperature at midnight and midday following application. Weather data were recorded with a CR-10X weather station datalogger fitted with an array of six model-237 leaf wetness sensors (Campbell Scientific, Logan, UT) (8).

\section{RESULTS}

Effect of temperature on germination and growth. Colonies of $M$. amaranthi on V8 agar grew fastest at $26^{\circ} \mathrm{C}$, and growth was severely limited at temperatures below $12^{\circ} \mathrm{C}$ or above $32^{\circ} \mathrm{C}$ (Fig. 1). Germination of conidia of $M$. amaranthi in potato dextrose broth was greatest at $20^{\circ} \mathrm{C}$ and was severely reduced at temperatures below $12^{\circ} \mathrm{C}$ or above $25^{\circ} \mathrm{C}$ (Fig. 1).

Duration and temperature of leaf wetness period. The severity of disease of common waterhemp caused by $M$. amaranthi and the largest dry weight reductions in common waterhemp were found when plants were maintained with $18 \mathrm{~h}$ of leaf wetness directly after application. Disease severity was greatest following leaf wetness periods at 18 or $23^{\circ} \mathrm{C}$. Disease severity was negligible following a leaf wetness period of $6 \mathrm{~h}$ or less (Table 1). Dry weight reductions were smaller with shorter leaf wetness periods and were nil when plants were not provided with a leaf wetness

TABLE 1. Effect of duration and temperature of leaf wetness upon the severity of disease of common waterhemp caused by Microsphaeropsis amaranthi in the greenhouse $\mathrm{e}^{\mathrm{x}}$

\begin{tabular}{lcccc}
\hline & \multicolumn{4}{c}{ Disease severity } \\
\cline { 2 - 5 } $\begin{array}{l}\text { Temperature during } \\
\text { leaf wetness period }\end{array}$ & \multicolumn{4}{c}{ Leaf wetness duration (h) } \\
\cline { 2 - 5 } $14^{\circ} \mathrm{C}$ & $0.00 \mathrm{e}^{\mathrm{z}}$ & $0.00 \mathrm{e}$ & $0.52 \mathrm{e}$ & $1.44 \mathrm{~d}$ \\
$18^{\circ} \mathrm{C}$ & $0.00 \mathrm{e}$ & $0.08 \mathrm{e}$ & $2.11 \mathrm{c}$ & $4.22 \mathrm{a}$ \\
$23^{\circ} \mathrm{C}$ & $0.00 \mathrm{e}$ & $0.04 \mathrm{e}$ & $2.27 \mathrm{c}$ & $3.28 \mathrm{~b}$ \\
$28^{\circ} \mathrm{C}$ & $0.00 \mathrm{e}$ & $0.04 \mathrm{e}$ & $1.33 \mathrm{~d}$ & $1.99 \mathrm{c}$ \\
\hline x Plants sprayed at three to four true leaf stage with $3 \times 10^{6}$ conidia per ml. \\
y Disease severity scored 10 days after application on the following rating \\
scale: $0=$ no disease, $1=$ slight flecking, 2 = mild disease symptoms $(<10 \%$ \\
necrosis), 3 = moderate/severe disease symptoms $(10$ to 50\% necrosis), $4=$ \\
severe disease symptoms ( $>50 \%$ necrosis), and 5 = plant death. Data are \\
from three trials combined. \\
z Means followed by the same letter do not differ significantly at $P=0.05$ \\
by Duncan's means separation using PROC GLM in SAS (SAS Institute, \\
Cary, NC).
\end{tabular}


period. Dry weight reductions were largest when the temperature during the leaf wetness period was 20 to $24^{\circ} \mathrm{C}$ (Fig. 2).

Effect of plant age and conidial concentration. Disease was most severe on younger common waterhemp, and was most severe when higher conidial concentrations were applied, although there was no significant effect on plant biomass of varying the conidial concentration (Table 2; Fig. 3). Biomass reductions in common waterhemp were greater when plants were treated at an earlier growth stage (Fig. 3).

Disease expression in the field. Of the 14 applications of $M$. amaranthi made to common waterhemp in the field in 2004, only seven resulted in disease. Of these, only three (13 May, 20 May, and 10 June) resulted in more than slight disease flecks (Table 3). Where disease occurred, M. amaranthi was successfully reisolated from plants. The weather conditions on each of 13 May, 20 May, and 10 June exhibited a leaf wetness period greater

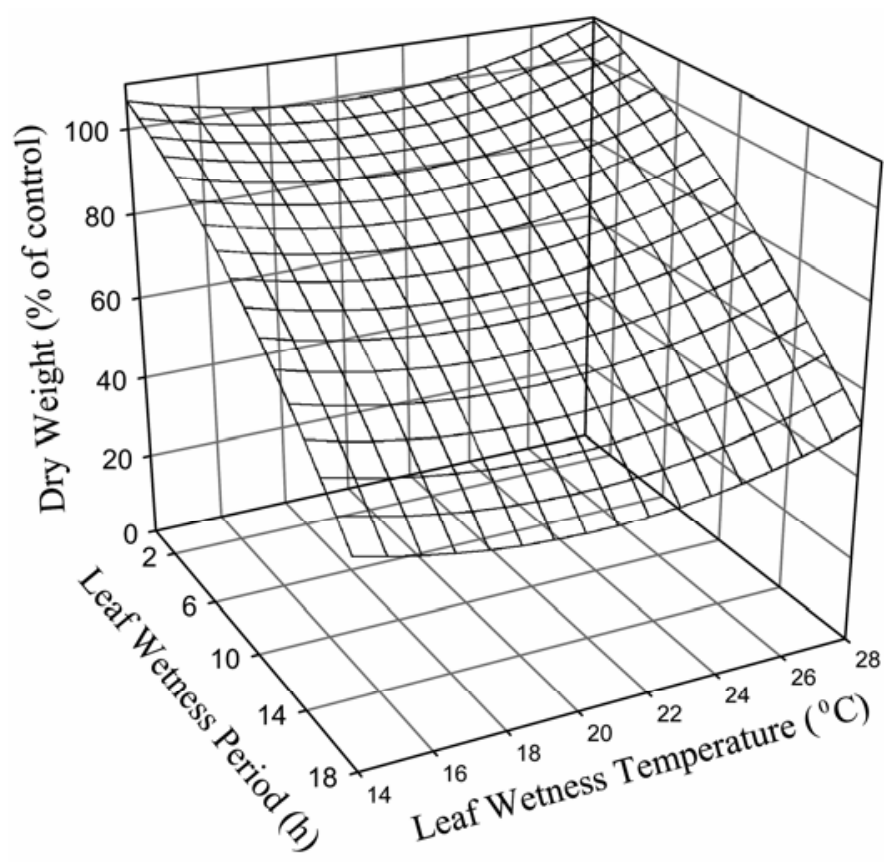

Fig. 2. Effect of duration and temperature of leaf wetness period on dry weight of waterhemp treated with Microsphaeropsis amaranthi in the greenhouse. Plants were sprayed at three- to four-true leaf stage with $3 \times 10^{6}$ conidia per $\mathrm{ml}$ and dry weights were measured 10 days after application. Regression was performed using PROC REG in SAS (SAS Institute, Cary, NC) from three combined trials. $R^{2}=0.46$.

TABLE 2. Effect of plant age and inoculum concentration upon the severity of disease of common waterhemp caused by Microsphaeropsis amaranthi in the greenhouse $^{\mathrm{x}}$

\begin{tabular}{lccccc}
\hline & \multicolumn{5}{c}{ Disease severity } \\
\cline { 2 - 6 } Plant & \multicolumn{5}{c}{ Inoculum concentration (conidia/ml) } \\
\cline { 2 - 6 } growth stage & 0 & $10^{5}$ & $10^{6}$ & $3 \times 10^{6}$ & $10^{7}$ \\
\hline Cotyledon & $0.00 \mathrm{~h}^{\mathrm{z}}$ & $2.94 \mathrm{c}$ & $2.96 \mathrm{~b}$ & $4.68 \mathrm{a}$ & $4.31 \mathrm{~b}$ \\
2- to 3-leaf stage & $0.00 \mathrm{~h}$ & $1.80 \mathrm{efg}$ & $2.09 \mathrm{de}$ & $2.35 \mathrm{~d}$ & $2.89 \mathrm{c}$ \\
4- to 6-leaf stage & $0.00 \mathrm{~h}$ & $1.78 \mathrm{efg}$ & $1.98 \mathrm{def}$ & $2.29 \mathrm{~d}$ & $2.72 \mathrm{c}$ \\
8- to 9-leaf stage & $0.00 \mathrm{~h}$ & $1.46 \mathrm{~g}$ & $1.68 \mathrm{fg}$ & $1.89 \mathrm{ef}$ & $2.12 \mathrm{de}$ \\
\hline
\end{tabular}

x Plants provided leaf wetness period of $18 \mathrm{~h}$ at $18^{\circ} \mathrm{C}$ after treatment.

${ }^{y}$ Disease severity scored 10 days after application on the following rating scale: $0=$ no disease, $1=$ slight flecking, $2=$ mild disease symptoms $(<10 \%$ necrosis), 3 = moderate/severe disease symptoms (10 to $50 \%$ necrosis $), 4=$ severe disease symptoms ( $>50 \%$ necrosis), and $5=$ plant death. Data are from two trials combined.

${ }^{\mathrm{z}}$ Means followed by the same letter do not differ significantly at $P=0.05$ by Duncan's means separation using PROC GLM in SAS (SAS Institute, Cary, NC). than $12 \mathrm{~h}$, moderate midnight temperatures above $18^{\circ} \mathrm{C}$, and moderate midday temperatures of $25^{\circ} \mathrm{C}$ or below the following day (Fig. 4). Even under these conditions, plants exhibited an average of less than $20 \%$ leaf necrosis and few plants were killed (Table 3). Weather data recorded in West Lafayette, IN, in 2002, 2003, and 2004 indicate that these moderate temperature conditions and long leaf wetness periods occur periodically, but are not common. In most cases, leaf wetness periods in excess of $12 \mathrm{~h}$ only occurred when it rained either the day of measurement or the following morning (Table 3; Fig. 4).

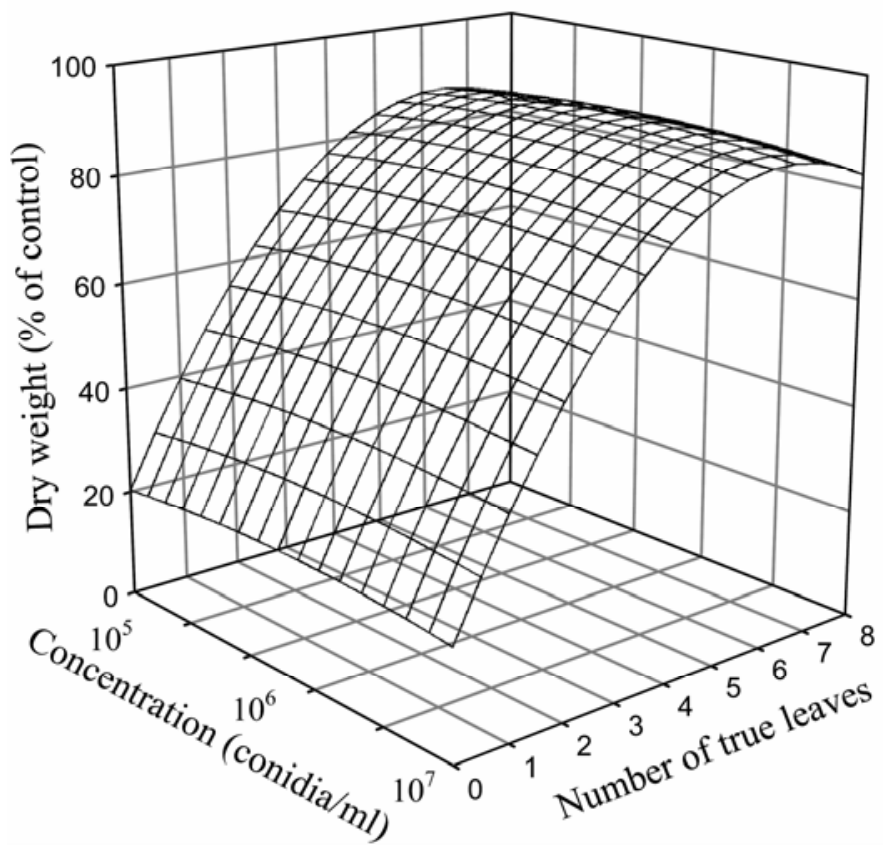

Fig. 3. Effect of plant age and Microsphaeropsis amaranthi conidial concentration on dry weight of waterhemp in the greenhouse. Plants were provided a leaf wetness period of $18 \mathrm{~h}$ at $18^{\circ} \mathrm{C}$ after application and dry weights were measured 10 days after application. Regression was performed using PROC REG in SAS (SAS Institute, Cary, NC) from two combined trials. $R^{2}=0.57$.

TABLE 3. Severity of disease of common waterhemp caused by Microsphaeropsis amaranthi following foliar application on different dates in the field (standard error of the means)

\begin{tabular}{lcccc}
\hline \multirow{4}{*}{$\begin{array}{l}\text { Date } \\
\text { sprayed }\end{array}$} & $\begin{array}{c}\text { Maximum } \\
\text { temperature }\end{array}$ & $\begin{array}{c}\text { Minimum } \\
\text { temperature }\end{array}$ & $\begin{array}{c}\text { Leaf wetness } \\
\text { duration }(\mathrm{h})\end{array}$ & $\begin{array}{c}\text { Disease } \\
\text { severity }\end{array}$ \\
\cline { 2 - 4 } seather parameters \\
\hline 15 April & $20.1^{\circ} \mathrm{C}$ & $14.5^{\circ} \mathrm{C}$ & 0.0 & $0.0(0.00)$ \\
22 April & $11.3^{\circ} \mathrm{C}$ & $8.4^{\circ} \mathrm{C}$ & 20.5 & $0.3(0.04)$ \\
29 April & $21.1^{\circ} \mathrm{C}$ & $17.2^{\circ} \mathrm{C}$ & 5.0 & $0.1(0.02)$ \\
6 May & $26.1^{\circ} \mathrm{C}$ & $21.8^{\circ} \mathrm{C}$ & 7.5 & $0.0(0.00)$ \\
13 May & $19.8^{\circ} \mathrm{C}$ & $20.9^{\circ} \mathrm{C}$ & 13.0 & $2.0(0.22)$ \\
20 May & $25.1^{\circ} \mathrm{C}$ & $23.7^{\circ} \mathrm{C}$ & 16.0 & $2.0(0.14)$ \\
27 May & $24.1^{\circ} \mathrm{C}$ & $19.0^{\circ} \mathrm{C}$ & 11.0 & $0.1(0.05)$ \\
3 June & $21.3^{\circ} \mathrm{C}$ & $10.5^{\circ} \mathrm{C}$ & 8.0 & $0.0(0.00)$ \\
10 June & $22.3^{\circ} \mathrm{C}$ & $18.9^{\circ} \mathrm{C}$ & 15.5 & $1.3(0.12)$ \\
17 June & $28.4^{\circ} \mathrm{C}$ & $20.4^{\circ} \mathrm{C}$ & 10.5 & $0.5(0.10)$ \\
24 June & $25.2^{\circ} \mathrm{C}$ & $12.7^{\circ} \mathrm{C}$ & 6.5 & $0.0(0.00)$ \\
1 July & $27.5^{\circ} \mathrm{C}$ & $18.7^{\circ} \mathrm{C}$ & 11.0 & $0.0(0.00)$ \\
8 July & $21.0^{\circ} \mathrm{C}$ & $20.0^{\circ} \mathrm{C}$ & 4.0 & $0.0(0.00)$ \\
15 July & $25.7^{\circ} \mathrm{C}$ & $19.0^{\circ} \mathrm{C}$ & 10.0 & $0.0(0.00)$ \\
\hline
\end{tabular}

${ }^{\mathrm{z}}$ Disease severity scored 14 days after application on the following rating scale: $0=$ no disease, $1=$ slight flecks on foliage or stems, $2=$ spreading lesions on the leaf or stem ( $<20 \%$ necrosis), $3=$ moderate to severe foliar symptoms (>20\% necrosis) or stem girdling, and $4=$ plant death. Data are from two trials combined. 


\section{DISCUSSION}

The optimal and limiting conditions for infection and impact of common waterhemp by $M$. amaranthi in the controlled environment have been determined. Growth and conidial germination of the fungus in culture were most rapid at 26 and $20^{\circ} \mathrm{C}$, respectively, infection of common waterhemp was greatest when the plant was maintained with leaf wetness at 20 to $24^{\circ} \mathrm{C}$, and the impact of the disease was less when plants were treated at later growth stages. Little biomass reduction was observed in plants sprayed later than the four true leaf stage. When plants were sprayed with conidial suspensions of $M$. amaranthi and then maintained in the field, infection by $M$. amaranthi was limited by weather conditions. Infection only occurred, other than occasional slight flecking, on 3 out of 14 application dates, each of which had a leaf wetness duration longer than $12 \mathrm{~h}$ and moderate temperatures during both the night and the following day. These weather conditions occur periodically in the region, but are not common.

It is encouraging that disease occurred in the field as a result of the spray application of unformulated aqueous suspensions of $M$. amaranthi onto unprotected common waterhemp; although we note that disease was only moderate even under these conditions. Likewise, the occurrence of up to $90 \%$ dry weight reductions in seedling common waterhemp under ideal conditions in the controlled environment is also encouraging. Clearly, however, although $M$. amaranthi can cause infection after spray application in the field, the environment poses severe limitations upon the expression of disease by this fungal plant pathogen. In order for $M$. amaranthi to be considered a serious bioherbicide candidate, significant improvements must be made to its field performance.

Numerous authors $(1-3,9,14)$ have suggested that the performance of foliar-applied bioherbicides can be improved by formulation, and improvements in efficacy and environmental tolerance have been made using various types of oil emulsion $(1,2,14)$. Nonetheless, these improvements have generally been somewhat modest, and it is not clear that the significant improvements required to ensure the reliable performance of $M$. amaranthi in the Midwestern United States would be met in this way.

Additional improvements to the $M$. amaranthi bioherbicide might be met through enhancement of the organism in the laboratory. Such enhancement might be achieved by cultural or nutritional means such as were demonstrated by the virulence enhancement of Sclerotinia minor (4) and Colletotrichum truncatum (13) by nutritional amendment. Alternatively, selection of high virulence strains (20) or modification of the fungus by mutagenesis (19) or transgenesis (10) may be feasible.

In summary, $M$. amaranthi possesses a number of desirable characteristics, including suitable host specificity, ease of growth in the laboratory, and virulence, and a high potential impact on the target weed under favorable conditions. We have shown, however, that the field environment of the Midwestern United States severely limits the infectivity and concomitant impact of $M$. amaranthi against common waterhemp. Future research will focus upon methods for the enhancement of the virulence and environmental resilience of the fungus.

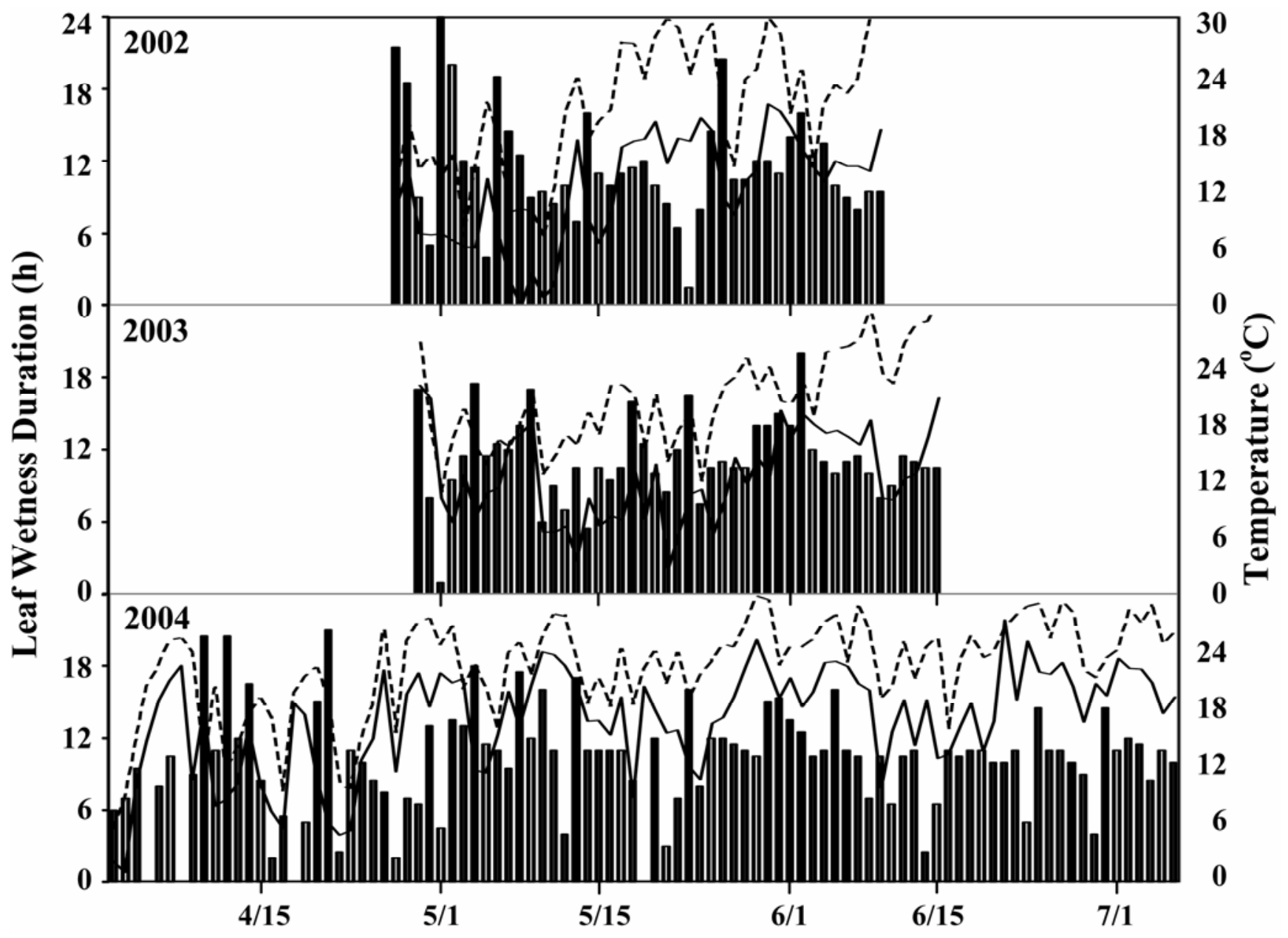

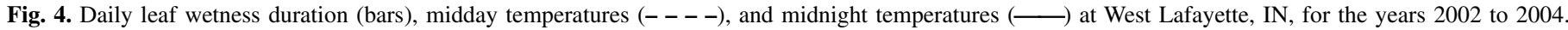

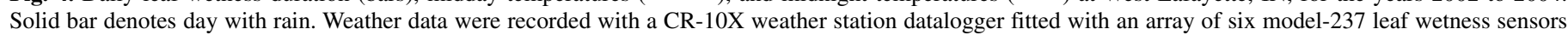
(Campbell Scientific, North Logan, UT). 


\section{ACKNOWLEDGMENTS}

We thank G. Beuchley and G. Shaner for the collection and sharing of weather data.

\section{LITERATURE CITED}

1. Amsellem, Z., Sharon, A., and Gressel, J. 1991. Abolition of selectivity of two mycoherbicidal organisms and enhanced virulence of avirulent fungi by an invert emulsion. Phytopathology 81:985-988.

2. Amsellem, Z., Sharon, A., Gressel, J., and Quimby, P. C., Jr. 1990. Complete abolition of high inoculum threshold of two mycoherbicides (Alternaria cassiae and A. crassa) when applied in invert emulsion. Phytopathology 80:925-929.

3. Boyette, C. D., Quimby, P. C., Jr., Caesar, A. J., Birdsall, J. L., Connick, W. J., Jr., Daigle, D. J., Jackson, M. A., Egley, G. H., and Abbas, H. K. 1996. Adjuvants, formulations and spraying systems for improvement of mycoherbicides. Weed Technol. 10:637-644.

4. Brière, S. C., Watson, A. K., and Hallett, S. G. 2000. Oxalic acid production and mycelial biomass yield of Sclerotinia minor for the formulation enhancement of a granular turf bioherbicide. Biocontrol Sci. Technol. 10:281-289.

5. Charudattan, R. 2001. Biological control of weeds by means of plant pathogens: Significance for integrated weed management in modern agroecology. BioControl 46:229-260.

6. Cordes, J. C., Johnson, W. G., Scharf, P., and Smeda, R. J. 2004. Lateemerging common waterhemp (Amaranthus rudis) interference in conventional tillage corn. Weed Technol. 18:999-1005.

7. Doll, D. A., Sojka, P. E., and Hallett, S. G. 2005. Factors affecting the efficacy of spray applications of the bioherbicidal fungus Microsphaeropsis amaranthi. Weed Technol. 19:110-115.

8. Gillespie, T. J., and Kidd, G. E. 1978. Sensing duration of leaf moisture retention using electrical impedance grids. Can. J. Plant Sci. 58:179-187.

9. Greaves, M. P., Holloway, P. J., and Auld, B. A. 1998. Formulation of microbial herbicides. Pages 203-233 in: Formulation of Microbial Pesticides. H. D. Burges, ed. Kluwer Academic, Dordrecht, the Netherlands.

10. Gressel, J. 2003. Enhancing microbiocontrol of weeds. ASM News 69:498-502.

11. Hallett, S. G. 2005. Where are the bioherbicides? Weed Sci. 53:404-415.
12. Hartzler, R. G., Bruce, B., and Nordby, D. 2004. Effect of common waterhemp (Amaranthus rudis) emergence date on growth and fecundity in soybean. Weed Sci. 52:242-245.

13. Jackson, M. A., Schisler, D. A., Slininger, P. J., Boyette, C. D., Silman, R. W., and Bothast, R. J. 1996. Fermentation strategies for improving the fitness of a bioherbicide. Weed Technol. 10:645-650.

14. Léger, C., Hallett, S. G., and Watson, A. K. 2001. Performance of Colletotrichum dematium for the control of fireweed (Epilobium angustifolium) improved with formulation. Weed Technol. 15:437-446.

15. Mintz, A. S., Heiny, D. K., and Weidemann, G. J. 1992. Factors influencing the biocontrol of tumble pigweed (Amaranthus albus) with Aposphaeria amaranthi. Plant Dis. 76:267-269.

16. Ortiz-Ribbing, L. M., and Williams, M. M., II. 2005. Potential of Phomopsis amaranthicola and Microsphaeropsis amaranthi as bioherbicides for several weedy Amaranthus species. Crop Prot. 25:39-46.

17. Patzoldt, W. L., Tranel, P. J., and Hager, A. G. 2002. Variable herbicide responses among Illinois waterhemp (Amaranthus rudis and A. tuberculatus) populations. Crop Prot. 21:707-712.

18. Patzoldt, W. L., Tranel, P. J., and Hager, A. G. 2005. A waterhemp (Amaranthus tuberculatus) biotype with multiple resistance across three herbicide sites of action. Weed Sci. 53:30-36.

19. Sands, D. C., Ford, E. J., and Miller, R. V. 1990. Genetic manipulation of broad host-range fungi for biological control of weeds. Weed Technol. 4:471-474.

20. Sands, D. C., and Pilgeram, A. 2001. Enhancing the efficacy of biocontrol agents against weeds. Pages 3-13 in: Enhancing Biocontrol Agents and Handling Risks. M. Vurro, J. Gressel, T. Butt, G. Harman, R. St. Leger, D. Nuss, and A. Pilgeram, eds. IOS Press, Amsterdam, the Netherlands.

21. Singleton, L. L., Mihail, J. D., and Rush, C. M. (eds.) 1982. Methods for Research on Soilborne Phytopathogenic Fungi. The American Phytopathological Society, St. Paul, MN.

22. Smith, D. A. 2003. Evaluation of Microsphaeropsis amaranthi as a bioherbicide for the control of waterhemp (Amaranthus tuberculatus). MS Thesis. Purdue University, West Lafayette, IN.

23. Smith, D. A., and Hallett, S. G. 2003. Compatibility of the candidate bioherbicide Microsphaeropsis amaranthi with herbicides and adjuvants in tank mixture. Pages 615-618 in: Proc. BCPC International Congress: Crop Science and Technology, BCPC, Alton, UK.

24. Templeton, G. E., TeBeest, D. O., and Smith, R. J. 1979. Biological weed control with mycoherbicides. Annu. Rev. Phytopathol. 17:301-310. 